\title{
Model Matematika pada Proses Hematopoiesis dengan Perlambatan Proses Proliferasi
}

\section{Mathematical Model on Hematopoiesis Process with Proliferation Time Delay}

\author{
Usman Pagalay, Anita Ambarsari \\ Jurusan Matematika Universitas Islam Negeri Maulana Malik Ibrahim Malang
}

\begin{abstract}
ABSTRAK
Proses produksi sel darah (hematopoiesis) pada kondisi normal diformulasikan dalam bentuk sistem persamaan diferensial nonlinier dengan waktu perlambatan. Waktu perlambatan menunjukkan durasi atau waktu yang diperlukan sel punca berada pada fase proliferasi. Penelitian ini bertujuan untuk menganalisis model matematika pada proses produksi sel darah meliputi analisis titik tetap dan perilaku populasi sel punca hematopoietik. Untuk mempelajari perilaku dinamik model, dilakukan dengan mempelajari persamaan karakteristik dari model tersebut. Hasil simulasi numerik menunjukkan bahwa untuk titik tetap nontrivial model mengalami osilasi. Osilasi pada model matematika proses hematopoiesis mengindikasikan bahwa hematopoiesis yang terjadi tidak stabil sehingga nantinya dapat diimplementasikan pada analisa adanya penyakit-penyakit yang mempengaruhi sel darah.
\end{abstract}

Kata Kunci: Hematopoiesis, osilasi, model matematika, waktu perlambatan

\section{ABSTRACT}

Blood cell production process (hematopoiesis) in normal conditions is formulated in the form of a nonlinear differential equation system with time delay. Time delay indicates the duration or time required for stem cells in the proliferative phase. This study aims to analyze the mathematical model of blood cell production process including fixed point analysis and hematopoietic stem cell population behavior. Studying the characteristics equations of the model was conducted to study the dynamic behavior of the model. The numerical simulation results show that for nontrivial fixed point model experiences oscillations. Oscillations in mathematical models of hematopoiesis process indicate that hematopoiesis occurs unstable so that they can be implemented on an analysis of the presence of diseases that affect blood cells.

Keywords: hematopoiesis, oscillation, mathematical models, time delay

Jurnal Kedokteran Brawijaya, Vol. 28, No. 2, Agustus 2014; Korespondensi: Usman Pagalay. Jurusan Matematika UIN Maulana Malik Ibrahim Malang, Jl. Gajayana No. 50 Malang 65144 Tel. (0341)551354Email: usmanpagalay@yahoo.co.id 


\section{PENDAHULUAN}

Hematopoiesis adalah proses pembentukan dan perkembangan berbagai tipe sel darah dan elemenelemen yang terbentuk lainnya. Produk akhir dari proses ini adalah sel darah merah, sel darah putih dan keeping darah (1). Para ahli biologi mengklasifikasikan sel punca hematopoietik menjadi sel proliferasi dan nonproliferasi. Sel proliferasi adalah sel-sel punca yang mempunyai sifat aktif berkembang dan berdiferensiasi sedangkan sel nonproliferasi adalah sel punca yang tidak aktif berkembang dan berdiferensiasi. Sel-sel nonproliferasi akan memasuki fase proliferasi dengan laju nonlinier untuk akhirnya berkembang dan berdiferensiasi membentuk sel-sel darah yang matur. Baik sel proliferasi maupun sel nonproliferasi dapat mengalami kematian karena adanya apoptosis (2)

Model matematika untuk dinamika sel punca hematopoietik telah diperkenalkan pada akhir tahun 1970 oleh Mackey (3). Proses produksi sel darah (hematopoiesis) diformulasikan dalam bentuk sistem persamaan diferensial biasa nonlinier orde satu dengan waktu perlambatan. Waktu perlambatan menunjukkan durasi yang diperlukan sel berada dalam fase proliferasi. Model matematika pada proses hematopoiesis diperbarui oleh Crauste dengan menggunakan laju perubahan sel nonproliferasi memasuki fase proliferasi dengan laju nonlinier yang bergantung pada populasi total sel punca (4). Penelitian ini menghasilkan sistem persamaan diferensial nonlinier dengan waktu tunda untuk populasi total sel punca dan sel nonproliferasi. Dalam penelitiannya Crauste menggunakan laju kematian yang sama antara sel proliferasi dan nonproliferasi. Dalam penelitian ini, berdasarkan model Crauste akan dilakukan analisis model matematika pada proses hematopoiesis dengan menggunakan laju kematian yang berbeda antara sel punca proliferasi dan sel nonproliferasi (4).

\section{METODE}

Langkah-langkah yang dilakukan dalam penelitian ini adalah Deskripsi kualitatif mengenai sifat-sifat pada sel punca hematopoietik, teori dasar tentang proses hemaopoiesis. Deskripsi kuantitatif tentang parameterparameter yang akan digunakan pada komputasi model matematika pada produksi sel darah. Jika tidak ada nilai parameter yang tersedia maka dilakukan estimasi parameter model atau dilakukan data proposional. Langkah selanjutnya adalah Membangun asumsi-asumsi sehingga ruang lingkup model berada pada koridor permasalahan yang akan dicari solusinya. Diasumsikan bahwa model matematika pada proses hematopoiesis berlaku pada kondisi normal. Konstruksi model pada proses hematopoiesis didasari model Crauste (4). Model tersebut melibatkan populasi sel punca proliferasi, populasi sel punca nonproliferasi, populasi total sel punca hematopoietik, dan waktu perlambatan untuk durasi sel punca berada pada fase proliferasi. Kemudian dilakukan penentuan parameter model. Parameter yang digunakan bersumber dari Adimy dkk (2). Yaitu $\gamma=0.1, \delta=0.05$, $\beta o=1.77, \theta=1, \eta=12$ Analisis kestabilan melalui persamaan karakteristik hasil linierisasi persamaan diferensial biasa nonlinier pada proses produksi sel darah. Linierisasi dan persamaan karakteristik diperlukan untuk mempermudah mencari solusi dari suatu sistem nonlinier. Simulasi. Metode numerik yang digunakan dalam menyelesaikan model matematika pada proses hematopoiesis adalah DDE23 dengan bantuan software matlab.

\section{HASIL}

\section{Konstruksi Model Matematika}

Model matematika yang digunakan untuk memahami proses pembentukan sel darah (hematopoiesis) meliputi populasi total sel punca yang kemudian terbagi menjadi dua jenis yaitu sel proliferasi dan sel nonproliferasi.

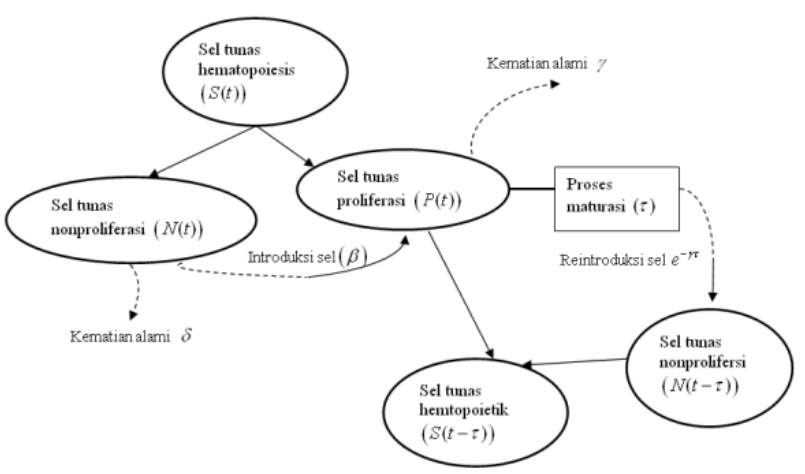

Gambar 1. Skema populasi sel tunas hematopoietik Keterangan:

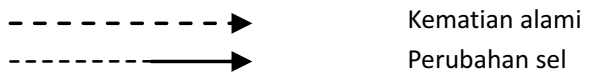

Variable-variable yang digunakan pada model adalah

$\mathrm{P}(t) \quad=$ Populasi sel proliferasi pada waktu $t$

$N(t) \quad=$ Populasi sel nonproliferasi pada waktu $t$

$S(t)=$ Populasi total sel punca hematopoietik pada waktu $t$

$\gamma \quad=$ Laju kematian sel proliferasi

$\delta \quad=$ Laju kematian sel nonproliferasi

$\beta \quad=$ Laju perubahan sel nonproliferasi memasuki fase proliferasi

$\mathrm{e}^{-\gamma \tau} \quad=$ Laju perubahan sel proliferasi kembali memasuki fase nonproliferasi

$\tau \quad=$ Lama waktu yang dihabiskan sel pada suatu fase

$\mathrm{S}(t-\tau)=$ Populasi total sel punca pada waktu $t$ dengan perlambatan $\tau$

$N(t-\tau)=$ Populasi sel nonproliferasi pada waktu $t$ dengan perlambatan sebesar $\tau$

Berdasarkan model Crauste (4) diperoleh model matematika pada proses produksi sel darah yang terdiri dari dua persamaan diferensial biasa dengan waktu tunda berikut ini:

$$
\begin{aligned}
& \frac{d S(t)}{d t}=-\gamma S(t)+(\gamma-\delta) N(t)+e^{-\gamma \tau} \beta(S(t-\tau)) N(t-\tau) \\
& \frac{d N(t)}{d t}=-\delta N(t)-\beta(S(t)) N(t)+2 e^{-\gamma \tau} \beta(S(t-\tau)) N(t-\tau)
\end{aligned}
$$

\section{Titik Kesetimbangan}

Titik kesetimbangan untuk sistem (1) diperoleh mencari nilai $\mathrm{S}(t)$ dan $\mathrm{N}(t)$ sedemikian sehingga $\frac{d S(t)}{d t}=0$ dan $\frac{d N(t)}{d t}=0$ Misalkan $S^{*}$ dan $N^{*}$ adalah titik tetap dari sistem persamaan (1), maka diperoleh:

$$
\left(S^{*}, N^{*}\right)=\left(S^{*}, \frac{\gamma\left(2 e^{-\gamma \tau}-1\right)}{\left(e^{-\gamma \tau}(2 \gamma-\delta)-(\gamma-\delta)\right)} S^{*}\right)
$$


Titik tetap pertama yang memenuhi persamaan (2) adalah $(0,0)$, dinotasikan dengan $E^{0}$

$$
\left(2 e^{-\gamma \tau}-1\right)>0, \quad \tau<\frac{\ln 2}{\gamma}
$$

Berdasarkan kondisi tersebut, karena $\beta$ adalah fungsi yang positif, menurun dan mempunyai limit 0 , maka ada $S^{*}>0$ yang memenuhi

$$
\left(2 e^{-\gamma \tau}-1\right) \beta\left(S^{*}\right)=\delta
$$

Jika dan hanya jika

$$
\left(2 e^{-\gamma \tau}-1\right) \beta(0)>\delta
$$

Persamaan (3) dan (4) ekuivalen dengan

$$
\beta(0)>\delta \quad \text { dan } \quad 0 \leq \tau \leq \bar{\tau}:=\frac{1}{\gamma} \ln \left|\frac{2 \beta(0)}{\delta+\beta(0)}\right|
$$

Teorema 1

Apabila berlaku ketidaksamaan (4) maka sistem persamaan (1) mempunyai tepat dua solusi yaitu $E^{0}=(0,0)$ dan

$$
\left(S^{*}, N^{*}\right)=\left(S^{*}, \frac{\gamma\left(2 e^{-\gamma \tau}-1\right)}{\left(e^{-\gamma \tau}(2 \gamma-\delta)-(\gamma-\delta)\right)} S^{*}\right)
$$

dimana $S^{*}$ adalah solusi dari persamaan (3). Dan jika $\left(2 e^{-\gamma \tau}-1\right) \beta(0) \leq \delta$ maka sistem persamaan (1) hanya mempunyai satu solusi trivial saja

Bukti:

i. Apabila berlaku $\left(2 e^{-\gamma \tau}-1\right) \beta(0)>\delta$ sehingga $\left(2 e^{-\gamma \tau}-1\right) \beta(0)>\delta$ $\left(2 e^{-\gamma \tau}-1\right) \beta(0)>0$ maka $\left(2 e^{-\gamma \tau}-1\right)>0$ sehingga diperoleh kestabilan dari sistem persamaan (1) adalah

$$
E^{*}=\left(S^{*}, N^{*}\right)=\left(S^{*}, \frac{\gamma\left(2 e^{-\gamma \tau}-1\right)}{\left(e^{-\gamma \tau}(2 \gamma-\delta)-(\gamma-\delta)\right)} S^{*}\right)
$$

ii. Apabila berlaku $\left(2 e^{-\gamma \tau}-1\right) \beta(0)=\delta$ sehingga $\left(2 e^{-\gamma \tau}-1\right) \beta(0)-$ $\delta=0$ diperoleh titik kestabilan $E^{0}=(0,0)$

iii. Apabila berlaku $\left(2 e^{-\gamma \tau}-1\right) \beta(0)=\delta$ sehingga $\left(2 e^{-\gamma \tau}-1\right) \beta(0)-$ $\delta<0\left(2 e^{-\gamma \tau}-1\right) \beta(0)<\delta$ diperoleh nilai kestabilan negatif.

Karena populasi tidak mungkin bernilai negative yang berarti terjadi kekurangan populasi, maka titik tetap dengan kondisi $\left(2 e^{-\gamma \tau}-1\right) \beta(0)<\delta$ tidak memenuhi sistem persamaan (1).

Linierisasi

Linierisasi adalah proses aproksimasi persamaan diferensial nonlinier dengan persamaan diferensial linier. Proses ini dilakukan dengan cara menghilangkan bagian nonlinier dari persamaan diferensial nonlinier menggunakan ekspansi deret Taylor disekitar titik kesetimbangan $\left(S^{*}, N^{*}\right)$

Persamaan linier dari sistem persamaan nonlinier (1) adalah

$$
\begin{aligned}
& \frac{d S(t)}{d t}=-\gamma S(t)+(\gamma-\delta) N(t)+e^{-\gamma \tau} \beta\left(S^{*}\right) N(t-\tau)+ \\
& e^{-\gamma \tau} N^{*} \beta^{\prime}\left(S^{*}\right) S(t-\tau) \\
& \frac{d N(t)}{d t}=-\left(\delta+\beta\left(S^{*}\right)\right) N(t)-N^{*} \beta^{\prime}\left(S^{*}\right) S(t)+ \\
& 2 e^{-\gamma \tau}\left(\beta\left(S^{*}\right) N(t-\tau)+N^{*} \beta^{\prime}\left(S^{*}\right) S(t-\tau)\right)
\end{aligned}
$$

Selanjutnya sistem persamaan (5) dapat ditulis dalam bentuk matrik

$$
\left(\begin{array}{c}
\frac{d S(t)}{d t} \\
\frac{d N(t)}{d t}
\end{array}\right)=A_{1}\left(\begin{array}{l}
S(t) \\
N(t)
\end{array}\right)+A_{2}\left(\begin{array}{c}
S(t-\tau) \\
N(t-\tau)
\end{array}\right)
$$

Dimana $A_{1}=\left(\begin{array}{cc}-\gamma & (\gamma-\delta) \\ -\alpha & -\left(\delta+\beta\left(S^{*}\right)\right)\end{array}\right)$ dan $A_{2}=e^{-\gamma \tau}\left(\begin{array}{cc}\alpha & \beta\left(S^{*}\right) \\ 2 \alpha & 2 \beta\left(S^{*}\right)\end{array}\right)$ untuk setiap $N^{*} \beta^{\prime}\left(S^{*}\right)=\alpha$

Persamaan karakteristik dari sistem persamaan (1) adalah

$$
\left|\left(\lambda I-A_{1}-A_{2} e^{-\lambda \tau}\right)\right|=0
$$

\section{Analisis Kestabilan Titik Kesetimbangan Trivial}

Salah satu titik kesetimbangan sistem persamaan (1) adalah kesetimbangan trivial yaitu $E^{0}=(0,0)$ Pada bagian ini, akan dianalisis kestabilan untuk titik kesetimbangan trivial.

\section{Teorema 2}

Pada titik kesetimbangan trivial, sistem persamaan (1) adalah

i. Stabil asimtotik lokal jika $\left(2 e^{-\gamma \tau}-1\right) \beta(0)<\delta$

ii. Stabil jika $\left(2 e^{-\gamma \tau}-1\right) \beta(0)=\delta$

iii. Tidak stabil jika $\left(2 e^{-\gamma \tau}-1\right) \beta(0)>\delta$

Bukti

Persamaan karakteristik persamaan (1) adalah persamaan (6) yang dapat ditulis sebagai

$$
\begin{aligned}
& {\left[\left(\lambda+\gamma-e^{-\lambda \tau} e^{-\gamma \tau} \alpha\right)\left(\lambda+\delta+\beta\left(S^{*}\right)-2 e^{-\lambda \tau} e^{-\gamma \tau} \beta\left(S^{*}\right)\right)\right]-} \\
& {\left[\left(\alpha-2 e^{-\lambda \tau} e^{-\gamma \tau} \alpha\right)\left(\delta-\gamma-e^{-\lambda \tau} e^{-\gamma \tau} \beta\left(S^{*}\right)\right)\right]=0}
\end{aligned}
$$

Untuk titik kesetimbangan $E^{0}=\left(S^{*}, N^{*}\right)=(0,0)$ maka $\alpha=N^{*} \beta^{\prime}\left(S^{*}\right)=0$ sehingga

$$
(\lambda+\gamma)\left(\lambda+\delta+\beta(0)-2 e^{-\lambda \tau} e^{-\gamma \tau} \beta(0)\right)=0
$$

Dari persamaan (7) diperoleh akar-akar karakteristik adalah $\lambda=-\gamma$ dan

$$
\left(\lambda+\delta+\beta(0)-2 e^{-\lambda \tau} e^{-\gamma \tau} \beta(0)\right)=0
$$

Persamaan (8) mempunyai satu solusi akar karakteristik yang bernilai riil misalkan $\lambda_{0}$ dan misalkan ada $\lambda$ yang merupakan akar-akar lain dari persamaan (8) dimana $\lambda \neq \lambda_{0}$ yang memenuhi $\operatorname{Re}(\lambda)<\lambda_{0}$. Misal diberikan suatu pemetaan $\lambda \rightarrow \lambda+\delta+\beta(0)-2 e^{-\lambda \tau} e^{-\gamma \tau} \beta(0)=0$ sebagai suatu fungsi dari $\lambda$ bernilai riil.

Diasumsikan bahwa $\lambda=\mu+\imath \omega \neq \lambda_{0}$ yang memenuhi persamaan (8). sehingga persamaan (8) menjadi

$$
\begin{aligned}
& \mu+i \omega+\delta+\beta(0)-2 e^{-(\mu+i \omega) \tau} e^{-\gamma \tau} \beta(0)=0 \\
& \mu+i \omega+\delta+\beta(0)-2 e^{-\mu \tau} e^{-\gamma \tau} \beta(0)(\cos \omega \tau-i \sin \omega \tau)=0
\end{aligned}
$$

Sehingga diperoleh persamaan untuk akar yang riil adalah

$$
\mu-\lambda_{0}=2 e^{-\gamma \tau} \beta(0)\left(e^{-\mu \tau} \cos \omega \tau-e^{-\lambda_{0} \tau}\right)=0
$$

Apabila bahwa $\mu=\lambda_{0}$. maka $2 e^{-\gamma \tau} \beta(0)\left(e^{-\mu \tau} \cos \omega \tau-e^{-\lambda_{0} \tau}\right)<0$ sehingga kontradiksi dengan yang diketahui bahwa $\mu \leq \lambda_{0}$. Apabila jika $\mu=\lambda_{0}$. maka diperoleh persamaan berikut. 


$$
\begin{aligned}
\lambda_{0}-\lambda_{0} & =2 e^{-\gamma \tau} \beta(0)\left(e^{-\lambda_{0} \tau} \cos \omega \tau-e^{-\lambda_{0} \tau}\right) \\
0 & =e^{-\lambda_{0} \tau} \cos \omega \tau-e^{-\lambda_{0} \tau} \\
\cos \omega \tau & =1 \quad \forall \tau \geq 0
\end{aligned}
$$

Hal ini mengakibatkan $\sin \omega \tau=0$. Berdasarkan bagan imaginer dari persamaan (9) diperoleh $\omega+2 e^{-\mu \tau} e^{-\gamma \tau} \beta(0) \sin \omega \tau=0$ sehingga diperoleh $\omega=0$ dan $\lambda=\lambda_{0}$. Kontradiksi dengan yang diketahui bahwa $\lambda \neq \lambda_{0}$ maka pengandaian salah dan $\mu<\lambda_{0}$, $\sigma$ ehingga akar riil $\lambda_{0}$ akan bernilai negatif jika $\left(2 e^{-\gamma \tau}-1\right) \beta(0)<\delta$. Dengan kondisi ini, akan diperoleh akar-akar riil dari sistem persamaan (1) bernilai negatif sehingga $E^{0}$ stabil asimtotik. Apabila $\left(2 e^{-\gamma \tau}-1\right) \beta(0)=\delta$ maka diperoleh akar dari persamaan (9) bernilai nol. Sehingga diperoleh akar-akar persamaan (1) adalah $\lambda=-\gamma$ atau $\lambda=0$ maka $E^{0}$ stabil. Apabila $\left(2 e^{-\gamma \tau}-1\right) \beta(0)>\delta$ maka akar persamaan (9) akan bernilai riil positif. Dengan kondisi ini, akan diperoleh salah satu akar riil dari sistem persamaan (1) bernilai positif sehingga $E^{0}$ tidak stabil.

\section{Analisis Kestabilan Titik Tetap Nontrivial}

Untuk kestabilan nontrivial sistem persamaan (1), diperoleh

$$
\begin{aligned}
& \beta\left(S^{*}\right)=\frac{\delta}{\left(2 e^{-\gamma \tau}-1\right)} \\
& \beta_{0} \frac{\theta^{n}}{\theta^{n}+\left(S^{*}\right)^{n}}=\frac{\delta}{\left(2 e^{-\gamma \tau}-1\right)} \\
& S^{*}=\theta\left[\frac{\left(2 e^{-\gamma \tau}-1\right) \beta_{0}}{\delta}-1\right]^{\frac{1}{n}}
\end{aligned}
$$

Sehingga

$$
N^{*}=\theta\left[\frac{\gamma\left(2 e^{-\gamma \tau}-1\right)}{\left(e^{-\gamma \tau}(2 \gamma-\delta)-(\gamma-\delta)\right)}\right]\left[\frac{\left(2 e^{-\gamma \tau}-1\right) \beta_{0}}{\delta}-1\right]^{\frac{1}{n}}
$$

Berdasarkan teorema 2 untuk menjamin bahwa diperoleh solusi yang nontrivial adalah berlakunya kondisi (4) yang ekuivalen dengan

$$
\beta(0)>\delta \quad \text { dan } \quad 0 \leq \tau \leq \bar{\tau}:=\frac{1}{\gamma} \ln \left|\frac{2 \beta(0)}{\delta+\beta(0)}\right|
$$

\section{Teorema 3}

Jika $\underline{\delta}<\underline{\beta}(0)$, maka titik kesetimbangan nontrivial adalah stabil asimtotik lokal.

Bukti:

Persamaan karakteristik dari sistem persamaan (1) adalah persamaan (6), jika $\tau=0$, maka persamaan (6) menjadi

$$
(\lambda+\gamma)\left(\lambda+\delta-\beta\left(S^{*}\right)-\alpha\right)
$$

Maka akar-akar dari persamaan (6) adalah

$$
\lambda=-\gamma \text { atau } \lambda=-\delta+\beta\left(S^{*}\right)+\alpha
$$

Karena $\beta$ adalah fungsi yang turun, maka untuk menjamin akar $\lambda=-\delta+\beta\left(\mathrm{S}^{*}\right)+\alpha$ bernilai riil negatif, maka $\delta<\beta(0)$

Untuk $\tau \neq 0$

Misalkan akar dari persamaan karakteristik (6) adalah $\lambda=i \omega$ sehingga persamaan menjadi

$$
\begin{aligned}
& (i \omega)^{2}+\left(\delta+\gamma+\beta\left(S^{*}\right)-2 e^{-i \omega \tau} e^{-\gamma \tau} \beta\left(S^{*}\right)-\alpha e^{-i \omega \tau} e^{-\gamma \tau}\right) i \omega \\
& +\alpha\left(e^{-i \omega \tau} e^{-\gamma \tau} \delta-e^{-i \omega \tau} e^{-\gamma \tau} \gamma+\gamma-\delta\right)+ \\
& \gamma\left(\delta+\beta\left(S^{*}\right)-2 e^{-i \omega \tau} e^{-\gamma \tau} \beta\left(S^{*}\right)\right)=0
\end{aligned}
$$

$$
\begin{aligned}
& \left(-\omega^{2}+\alpha \gamma-\alpha \delta+\gamma \delta+\gamma \beta\left(S^{*}\right)\right)^{2}+\left(\delta+\gamma+\beta\left(S^{*}\right)\right)^{2} \omega^{2} \\
= & \left(2 e^{-\gamma \tau} \beta\left(S^{*}\right)+\alpha e^{-\gamma \tau}\right)^{2} \omega^{2}-\left(\alpha e^{-\gamma \tau} \delta-\alpha e^{-\gamma \tau} \gamma-2 e^{-\gamma \tau} \beta\left(S^{*}\right) \gamma\right)^{2} \\
& \omega^{4}+\left(\delta^{2}+2 \delta \beta\left(S^{*}\right)+\beta\left(S^{*}\right)^{2}+\gamma+2 \alpha \delta-\gamma \delta\right) \omega^{2} \\
& +\left(\alpha \gamma-\alpha \delta+\gamma \delta+\gamma \beta\left(S^{*}\right)\right)^{2}-\left(\alpha e^{-\gamma \tau} \delta-\alpha e^{-\gamma \tau} \gamma-2 e^{-\gamma \tau} \beta\left(S^{*}\right) \gamma\right)^{2}=0
\end{aligned}
$$

Maka persamaan (12) dapat ditulis menjadi

$$
\lambda^{2}+\mathrm{p} \lambda+\mathrm{q}=0
$$

Karena $\beta=\left(S^{*}\right)$ dalah fungsi yang turun, maka persamaan (13) memiliki nilai $p>0, q>0$ apabila berlaku ketaksamaan (11) sehingga persamaan (13) mempunyai solusi bernilai riil negatif atau bernilai kompleks dengan bagian riilnya negatif. Oleh karena itu, disebut asimtotik lokal.

\section{Simulasi Numerik}

Pada bagian ini, akan ditampilkan grafik solusi numerik dari sistem persamaan (1) dengan menggunakan bantuan software matlab dan metode DDE23.

Parameter yang digunakan adalah

$$
\delta=0.1, \gamma=0.05, \beta_{0}=1.77, \mathrm{n}=12
$$

Sebagai perbandingan, akan diberikan beberapa perubahan kondisi untuk perlambatan waktu.

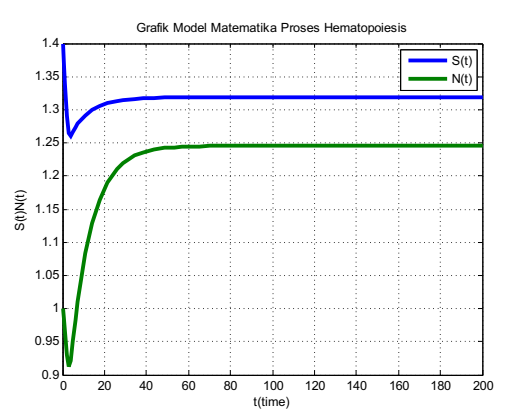

Gambar 2. Grafik model populasi sel punca hematopoietik
dengan $\tau=1$

Gambar 2 menunjukkan perilaku populasi total sel punca hematopoietik dan sel nonproliferasi dengan waktu perlambatan $\tau=1$. Populasi kedua sel pada beberapa hari pertama mengalami penurunan kemudian pada hari ke 5 sama-sama mengalami kenaikan yang tajam hingga pada akhirnya mencapai stabil pada hari ke 50. Populasi sel nonproliferasi lebih rendah daripada sel nonproliferasi karena sel nonproliferasi merupakan bagian dari sel tunas.

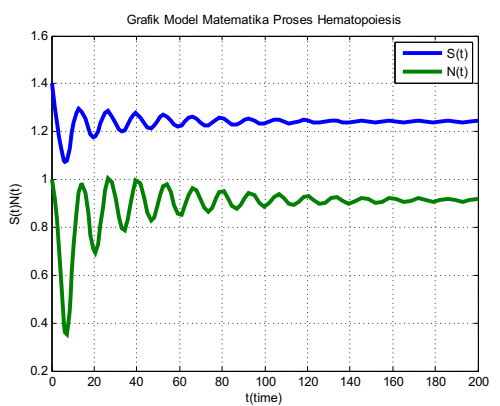

Gambar 3. Grafik model populasi sel punca hematopoietik dengan $\tau=3.5$ 
Gambar 3 menunjukkan perilaku populasi total sel punca hematopoietik dengan sel nonproliferasi dengan waktu perlambatan $\tau=3.5$. Baik sel punca maupun sel proliferasi mengalami osilasi pada hari ke 20. Osilasi dalam hal ini menunjukkan bahwa proses produksi sel darah yang terjadi di dalam sum-sum tulang tidak stabil. Populasi sel punca mulai menuju stabil pada hari ke 140 , sedangkan populasi sel nonproliferasi masih menunjukkan adanya osilasi sampai hari ke 200

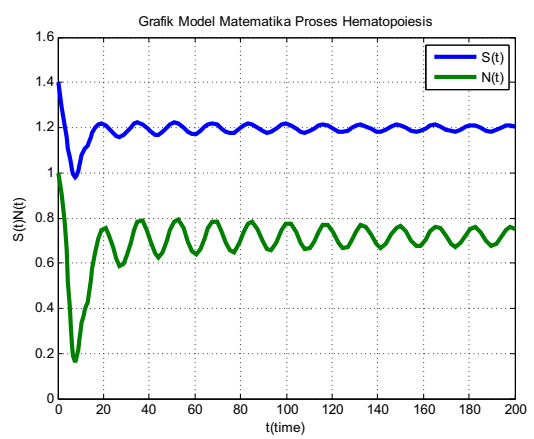

Gambar 4. Grafik model populasi sel punca hematopoietik dengan $t=4.25$

Gambar 4 menunjukkan perilaku populasi sel Punca hematopoietik dengan sel nonproliferasi dengan waktu perlambatan $\tau=4.52$. Pada keadaan ini populasi sel punca dan sel nonproliferasi terus mengalami osilasi bahkan sampai hari ke 200. Kedua populasi sel tersebut tidak dapat stabil.

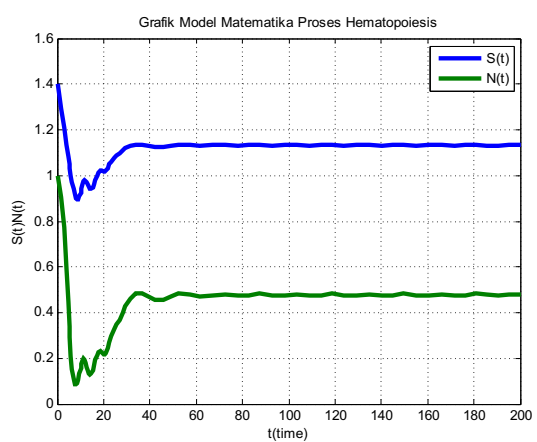

Gambar 5. Grafik model populasi sel punca hematopoietik dengan $\mathrm{t}=5.5$

Gambar 5 menunjukkan perilaku populasi total sel punca hematopoietik dengan sel nonproliferasi dengan waktu perlambatan $\tau=5.5$ kedua sel mengalami osilasi yang kecil pada hari ke 5 sampai hari ke 50 . Populasi sel terlihat menuju stabil lagi pada hari ke 50.

Berdasarkan keempat gambar di atas, model matematika pada proses hematopoiesis stabil untuk waktu perlambatan $\tau<3.5$ dan akan mengalami osilasi pada $3.5 \leq \tau \leq 5$. Model akan kembali stabil pada $\tau>5$.5. Ketika $\tau$ mengalami kenaikan pada interval model mengalami osilasi, maka osilasi akan semakin besar dapat dilihat pada gambar 4. Fenomena ini telah dipelajari oleh Pujo dan
Mackey (6). Hal ini dapat direlasikan dengan penyakitpenyakit yang mempengaruhi sel darah yang dapat dilihat dari osilasi sirkulasi jumlah sel darah dengan lama periode dan durasi siklus sel.

\section{DISKUSI}

Dalam penelitian ini model matematika pada proses produksi sel darah adalah model yang diformulasikan oleh Crauste (4) yang merupakan modifikasi model Mackey (3). Jika dalam model Crauste (4) diasumsikan laju kematian sama antara sel proliferasi dan nonproliferasi, maka dalam penelitian ini diasumsikan laju kematiannya adalah berbeda. Dalam contoh untuk hasil simulasi numerik menunjukkan bahwa jika digunakan laju yang sama antara sel proliferasi dan nonproliferasi diperoleh bahwa sistem persamaan pada proses pembentukan sel darah mengalami osilasi ketika diberikan perlambatan waktu 3.5 hari dan akan kembali stabil pada perlambatan waktu 9 hari (4). Jika digunakan laju kematian yang berbeda antara sel prolifersi dan nonproliferasi sebagaimana yang diberikan dalam persamaan 13 , maka sistem persamaan pada proses produksi sel darah mengalami osilasi pada waktu perlambatan 3.5 hari dan kembali stabil pada perlambatan waktu 5.5 hari. Hal ini menunjukkan bahwa laju kematian sel punca proliferasi dan nonproliferasi mempengaruhi kestabilan sistem persamaan pada proses produksi sel darah.

Model matematika untuk populasi sel punca hematopoietik dengan laju kematian yang berbeda antara sel proliferase dan sel nonproliferase adalah

$$
\begin{aligned}
& \frac{d S(t)}{d t}=-\gamma S(t)+(\gamma-\delta) N(t)+e^{-\gamma \tau} \beta(S(t-\tau)) N(t-\tau) \\
& \frac{d N(t)}{d t}=-\delta N(t)-\beta(S(t)) N(t)+2 e^{-\gamma \tau} \beta(S(t-\tau)) N(t-\tau)
\end{aligned}
$$

Dua titik kesetimbangan yaitu

$$
E^{0}=(0,0) \text { dan }\left(S^{*}, N^{*}\right)=\left(S^{*}, \frac{\gamma\left(2 e^{-\gamma \tau}-1\right)}{\left(e^{-\gamma \tau}(2 \gamma-\delta)-(\gamma-\delta)\right)} S^{*}\right)
$$

Dengan suatu kondisi perlu yaitu $\left(2 e^{-\gamma \tau}-1\right) \beta(0)>\delta$

Kestabilan pada solusi trivial $E^{0}=(0,0)$

I. Stabil asimtotik lokal jika $\left(2 e^{-\gamma \tau}-1\right) \beta(0)<\delta$

ii. Stabiljika $\left(2 e^{-\gamma \tau}-1\right) \beta(0)=\delta$

iii. Tidak stabil jika $\left(2 e^{-\gamma \tau}-1\right) \beta(0)>\delta$

Untuk solusi nontrivial apabila berlaku $\delta<\beta(0)$ dan $\tau=0$ maka model matematika untuk proses hematopoiesis adalah stabil asimtotik

Hasil grafik untuk model matematika proses hematopoiesis dengan menggunakan bantuan software matlab dengan berbagai nilai waktu tunda menunjukkan bahwa waktu tunda mempengaruhi kestabilan dari sistem. Sistem mulai mengalami osilasi ketika pada kondisi perlambatan sebesar 3.5, dan osilasi terbesar ketika berada pada kondisi perlambatan 4.52. Sistem akan mulai stabil lagi ketika berada pada konsdisi dengan perlambatan sebesar 5.5. Dalam hal ini perlambatan juga mempengaruhi titik tetap dari sistem, yaitu apabila semakin besar nilai perlambatan, maka sistem akan menuju nol. Hal ini mengindikasikan terjadinya pemusnahan sel ketika nilai perlambatan menuju infinit. 


\section{DAFTAR PUSTAKA}

1. Williams L. Comprehensive Review of Hematopoiesis and Immunology: Imaplications for Hematopoietic Stem Cell Transplant Recipients. In: Ezzone S (Ed). Hematopoietic Stem Cell Transplantation: A Manual for Nursing Practice. Pittsburg: Oncology Nursing Society; 2004; p. 1-13.

2. Adimy M, Crauste F, and Ruan S. A Mathematical Study of the Hematopoiesis Process with Application to Chronic Myelogenous Leukemia. [Thesis]. University of Miami, Miami. 2004.

3. Mackey MC. Unified Hypothesis of the Origin of Aplastic Anemia and Periodic Hematopoiesis. Blood. 1978; 51(5): 941-956.

4. Crauste F. Global Asymptotic Stability and Hopf Bifurcation for a Blood Cells Production Model. Mathematical Bioscience and Engineering. 2006; 3(2): 325-346.

5. Pujo-Menjouet L and Mackey MC. Contribution to the Study of Periodic Chronic Myelogenous Leukemia.
Comptes Rendus Biologies. 2004; 327(3): 235-244.

6. Howard A dan Chris R. Aljabar Linear Elementer: Versi Aplikasi Jilid 1. Jakarta: Erlangga; 2004.

7. Ayres F dan Ault JC. Theory and Problem of Differential Equations SI (Metric) Edition (Schaum Series). Jakarta: Erlangga; 1984.

8. Cain JW and Reynolds AM. Ordinary and Partial Differential Equation: An Introduction to Dynamical System. Virginia: Center for Teaching Excellence; 2010.

9. Finizio N and Ladas G. An Introduction to Differential Equation with Difference Equation, Fourier Analysis, and Partial Differential Equations. California: Wadsworth; 1982.

10. Pagalay U. Mathematical Modeling (Aplikasi Pada Kedokteran, Imunologi, Biologi,Ekonomi, Perikanan). Malang: UIN Press; 2009.

11. Robinson RC. An Introduction to Dynamical Systems Continuous and Discrete. New Jersey: Pearson Education Inc; 2004. 